\title{
Values of Indigenous Meeting (Sangkep) Bali Indigenous Peoples in the Establishment of Civic Disposition
}

\author{
I Made Darsana \\ Graduate Student of Civic Education Department \\ Universitas Pendidikan Indonesia \\ Bandung, Indonesia \\ imadedarsana@student.upi.edu
}

\author{
Elly Malihah \\ Lecturer of Sociology Education, Faculty of Social Science \\ Education \\ Universitas Pendidikan Indonesia \\ Bandung, Indonesia \\ ellyms@upi.edu
}

\author{
Muhammad Halimi \\ Lecturer of Civic Education Department, Faculty of Social Science Education \\ Universitas Pendidikan Indonesia \\ Bandung, Indonesia \\ mhalimi58@yahoo.com
}

\begin{abstract}
This research is motivated by the problem of lack of tolerance and mutual respect for the opinions of others when discussing which is marked by the difficulty of deliberating in the community. The problem studied in this study is what values are found in the indigenous meeting (sangkep) in the community there is Bali in Buyut Baru village so that it can form the character of democratic citizens in the village. In this study using a qualitative approach with case study methods. The object in this study is the cloak activity in the indigenous people of Bali with the speakers of traditional leaders and the community. The results of the research found by researchers is that the implementation of indigenous meeting (sangkep) in Buyut Baru village gives value to Balinese traditional communities in every stage of their activities including discipline, gotong royong, independence, courage to express opinions, tolerance, and always deliberating. In the community has an important role in shaping the attitudes and character of the community, through indigenous meeting (sangkep) the cultivation of knowledge and values of democratic life continues.
\end{abstract}

Keywords-bali indigenous peoples; civic disposition; deliberation; indigenous meeting (sangkep)

\section{INTRODUCTION}

Deliberation is a form of values living habits in Indonesian society, therefore it is no surprise when the founder of Indonesia to enter consultation as part of the noble values of Pancasila as the state. Pancasila is a mirror of the habits in the society, then poured in a basic form state. Similarly, the Indonesian people's habits of various tribes, deliberation appears to be a way for the settlement of all disputes between them.

In Indonesia, the principles of democracy have been prepared in accordance with the values that grow in the community, although it must be said is merely a procedural democracy, the decision making process to put forward a vote rather than deliberation, which is actually the original principles of democracy in Indonesia [1], The concept of Pancasila democracy excavated from the original value of Indonesian society with the values attached to him, like a village democracy, collectivism meeting, consensus, mutual help and other terms related to it. The goal, provide empirica sociological grounding of the concept of democracy in accordance with the nature of community life native to Indonesia. About how the workings of deliberative democracy, Hatta advocated the need to tread on the traditions of the village consultative. However, he cautioned that not everything that looks good on village democracy can be used just like that on the state level [2]. Therefore, the tradition of consensus in the village is an example of that recommended for the implementation of democracy in Indonesia.

Since the first pattern of settlement of disputes/ lawsuits in Indonesian society is based on consensus, for example in the form of village consultation, the density of traditional, customary justice, the judiciary village, burn stone culture, begundem institutions and others. Therefore, with benchmarks so people should prefer peace in settling disputes/ disputes. Paths of consultation is the main pathway used indigenous and tribal peoples in resolving cases/ disputes, because in deliberation will be made the peace agreement beneficial to both parties [3]. It can be stressed that the compromise approach or consensus deliberation aims to find common ground between different interests until an agreement is produced. This process is in addition to saving time for case resolution but is also carried out in a simple and low cost manner. 
In Balinese indigenous communities there is a very good habit, where the tradition of deliberation called pasangkepan is always put forward. The next step is to curb the implementation of the pakraman village administration through awig-awig in force in the Pakraman village. The sangkep tradition is the habit of deliberation to reach consensus among Balinese indigenous people in solving problems that arise. All social problems that exist are attempted to be decided internally through the paruman or pesangkepan.

Firmness in implementing the Bali community wherever they are ancestral traditions shows the character of indigenous Balinese very respect and appreciate the great value that is inherited. Character formation that occurs on an ongoing basis from an early age to adults through customs. Neither the indigenous people of Bali in Buyut Baru Village, although an immigrant community but can adapt and adjust with the diversity found in the village. Balinese indigenous people in Buyut Baru village also carry out ancestral traditions such as those on the island of Bali, one of which is the habit of gathering to discuss problems that occur in the village and deliberate to find solutions to these problems which are usually carried out in indigenous meeting (sangkep).

Customs and traditions that became one of the riches Indonesia (local genius) should be the basis for the implementation of education in Indonesia, especially in terms of character education and civic education (civic education). Cultural education have relevance mutually affect one another and can not be separated. As is known in the culture contained cultural values that can shape the human character. Therefore, the culture and traditions of the tribes in the area needs to be studied scientifically and deep to know the cultural values it contains, to be used as an ingredient in fostering education in Indonesia. Cultural values found then sorted to determine which values can be used to be developed in order to construct a system and method of education that can be used by educational institutions and educators for teaching and learning.

\section{LITERATURE REVIEW}

\section{A. Pancasila Democracy}

Pancasila democracy is a democracy that is based on the principle of kinship and mutual cooperation aimed at the welfare of the people, which contains elements of religious conscience, truth, love and noble character, personality Indonesia and sustainable. According to Hatta, the principle of Pancasila on God becomes the basic precepts that lead to another. As well as populist or democratic precepts, Hatta confident that democracy will live forever on earth Indonesia, though will experience high tide and low tides.

According to Prof. Darmo Dardji Diharjo, SH, Pancasila Democracy is the idea of democracy that comes to personality and philosophy of life of the Indonesian nation such embodiments, the provisions of the preamble 1945. Then Prof. Dr. Drs. Notonegoro, SH, Pancasila Democracy is democracy, led by the inner wisdom of deliberations / representatives, as well as by fostering a social justice for all people appears logical. (The same notion later expressed also by Soemantri,
SH and Drs. S. Padmuji, MPA.). Then B Arif Sidharta, said Pancasila is a view of life that core belief that humans were created in solidarity with each other, "men are created in togetherness with each other" [4].

Pancasila Democracy is also interpreted as democracy internalized by the nation of Indonesia animated and integrated by the noble values of Pancasila. In a democracy of Pancasila, the state organizing system carried out by the people themselves or with the consent of the people, where the nobility of man as a creature of God in the political, economic, social, cultural and security defense is recognized, adhered and secured on the basis of state ideology.

In Indonesia, the principles of democracy have been prepared in accordance with the values that grow in the community, although it must be said is merely a procedural democracy, the decision making process to put forward a vote rather than deliberation, which is actually the original principles of democracy in Indonesia.

The concept of Pancasila democracy excavated from the original value of Indonesian society with the values attached to him, like a village democracy, collectivism meeting, consensus, mutual help and other terms related to it. The goal, provide empirical sociological grounding of the concept of democracy in accordance with the nature of community life native to Indonesia.

\section{B. Indigenous Meeting (Sangkep)}

From the literature search is known that indigenous justice anywhere in Indonesia took place through a traditional mechanism in the customary discussion forum ("indigenous Meeting " or "customary meeting"), which in various places in Indonesia called the typical expression of each region. In the deliberations, the role of traditional chiefs is very important and prominent, namely the leader of deliberation [5].

In indigenous people of Bali are two terms that refers to activities that pesangkepan and Paruman deliberation. Grammatically, of these terms is not reflected by the specific concept of justice, because these terms are common meaningful. Pesangkepan basic words kasangkepang is "sangkep", whereas the basic word "Paruman" is "paum"; both contain the same meaning, namely meetings, convene or conduct meetings.

In the deliberations, the role of traditional chiefs is very important and prominent, namely the leader of deliberation. As ever written by Soepomo, the heads of customs has a very important task in the administration of justice, including activities to prevent violations of the law ("preventieve rechtszorg") and to revise the law if the law was violated ("repressieve rechtszorg") [6].

\section{Civic Disposition}

Citizenship education is an appropriate means to internalize the character values of the nation. According Winataputra and Budimansyah, Citizenship Education is the subject of learning with the mission to establish a national identity, which is a conscious effort in "nation and character building." In this context the role of Citizenship Education for the survival of the 
nation and state is very strategic. A democratic state must ultimately rely on the knowledge, skills and virtues of the citizens and the people they choose to hold public office [7].

Competence citizenship by Branson is divided into three, namely: 1) Civic Knowledge, relating to the content or what is supposed to be known by citizens; 2) Civic Skill, is the intellectual and participatory skills relevant citizens; and 3) Civic Disposition, which hinted at the public or private character that are important for the maintenance and development of constitutional democracy. Components disposition citizenship refers to personal character traits and social character that is required for maintenance and repair of constitutional democracy. This component includes the personal character traits such as moral responsibility, selfdiscipline, and respect for the value and dignity of humanity. Civic character traits among others such as community spirit, good manners, respect for the rule of law, critical thinking, the desire to listen, negotiate, and compromise is indispensable for the success of democracy [8].

\section{METHOD}

The use of qualitative research approach with case study method in this study is intended to determine the condition of an objective and in-depth research focus. A case study approach chosen because of concerns that the research being focused only occur in a certain place, namely in the village of Buyut Baru, Seputih Raman District of Central Lampung regency. In its implementation, many more researchers to use inter-personal approach in this study, which means that during the research process the researcher more direct contact with people in the village of Buyut Baru, Seputih Raman District of Central Lampung regency especially with the village head, the head of customs, figures from traditional leaders, and the community. Data collection techniques in this study using observation, interview and documentation. Later the result data obtained were analyzed through data reduction, data presentation, and draw some conclusions / verification.

\section{RESULTS AND DISCUSSION}

Based on the results of this research is that there are values in the indigenous meeting (sangkep) indigenous people of Bali in Buyut Baru Village an impact on attitude formation and character of society. In the implementation of indigenous meeting (sangkep), the community was invited to gather together to discuss various matters relating to the survival of the Balinese indigenous people in Buyut Baru Village such as religious activities and gotong royong. In addition, these activities can be used to discuss the customary violations that occurred in Buyut Baru Village and the sanctions that will be received.

The interview with one of the traditional leaders in Buyut Baru Village, shows indigenous meeting (sangkep) lasting value investment of democratic life indirectly and unconsciously by the people who participate in these activities. Society embedded value to be able to receive any ideas and arguments of each participant indigenous meeting (sangkep) so that every community can channel their aspirations without fear and intimidated. Indigenous meeting (sangkep) is also used as a place by the public to seek redress when problems customary inheritance disputes, land, and others. Settlement of disputes in the indigenous meeting (sangkep) the importance of "the principle of complete", cultivated implementation such that the parties can still continue living together as they were before the problem occurred. Completion of using this doctrine leads to efforts to restore peace and harmony in the relationships that have been there before, good relations between the parties in question as well as other relationships in society. Therefore, in dealing with the problem by using the teachings of the principle put forward to resolve this very harmonious and barrel by using ways of deliberation to reach consensus.

Once the researchers conducted observations, interviews, documentation and participation in the activities of the indigenous meeting (sangkep) in Buyut Baru Village concluded that there planting values in these activities unnoticed by the people who carry it out. The values contained within indigenous meeting (sangkep) in Buyut Baru Village, among others:

\section{A. Discipline}

Disciplining yourself in any activity can be indigenous people to always discipline in other activities outside the traditional, so that activities can be organized in an orderly society and people can be independent.

\section{B. Gotong Royong}

In carrying out the activities of building indigenous peoples jointly, they embrace the embarrassment of contributions for the establishment of facilities for adat, because indigenous peoples will also use the facilities.

\section{Independent}

Independence of indigenous peoples looks when building does not depend on other parties outside the customary, because people carry out on the basis of mutual agreement in indigenous meeting (sangkep).

\section{Freedom of Speech}

In the indigenous meeting (sangkep) each received and discussion aspirations of the community together for the advancement of indigenous people themselves, so that people are not shy in conveying any idea / ideas.

\section{E. Discussion}

One form of customary consultation meeting is all that is in the question and answer session where any suggestions from the community discussed together and decided for the common good. In deliberation, weighing customary institutions based on the opinions of all the people present.

\section{F. Tolerance}

In each question and answer always there are different opinions, but the community always responds kindly and respectfully to other indigenous communities. Tolerance values like this usually guide the Balinese indigenous people in the 
Buyut Baru village to produce agreements and decisions are always adhered to by the people.

Implementation of the indigenous meeting (sangkep) in Buyut Baru Village give value to the planting of indigenous Bali in every stage activities include self-discipline, mutual cooperation, independent, bold expression, mutual respect, tolerance, and always consulted. The customs carried out by the indigenous people of Bali in Buyut Baru village provide a positive experience to the community so that in carrying out each activity the community can apply the values that have been learned in a diverse community such as those in Buyut Baru village. In the customary meeting every citizen is given the opportunity to give their own opinion, which is then taken decisions by consensus [9].

In connection with the autonomy of indigenous villages / pakraman in Bali, Sally Falk Moore with the theory of the semi-autonomous social field stated Law is the self-regulation of a semi-autonomous social field. Autonomy means that emphasis on the ability to create rules that apply in their own environment, as well as encouraging or forcing the residents to obey these rules. But on the other hand, rules, customs, selfcreated symbols are susceptible to the rules, decisions and forces of the greater and surround them [10].

Bali society generally known as a community that is very consistent with the activities of customs in everyday life. Activities of customs and practices that are commonly practiced e.g. sangkep activities, both sangkep Village, sangkep Teruna-Teruni, sangkep Subak, or making a proposal. Sangkep (indigenous meeting) is a traditional activity that aims to unify thoughts or ideas between citizens throughout the village within the scope of certain indigenous villages to reach agreement [11].

The essence of the deliberations as legal drafting system is a way to find and gather the opinions of the truth through scientific discussion. This way is a tremendous opportunity for the participants to have a dialogue with the foundation of scientific argumentation. Deliberation plays an important role as a shield of the people, because they it is a vehicle for people to express the will and thought, and deliberation, to avoid the leader of the arbitrary attitude [12].

Balinese community strongly supports indigenous meeting (sangkep), in addition to an ancestral tradition that should continue to be preserved, these activities also have a positive impact to the community. The community becomes more respectful of each other and a sense of kinship between communities can reduce the risk of conflict that can occur at any time. People have become more responsible to the environment due to activities planning mutual assistance in indigenous meeting (sangkep) and have more concern for others.

\section{CONCLUSION}

Implementation of the indigenous meeting (sangkep) in Buyut Baru Village provide value investment that are beneficial to society that can be applied in everyday life. The value Planting gone unnoticed by the public so that people become accustomed to applying these values. Planting occurs in every stage of value to society indigenous meeting (sangkep) such as self-discipline, gotong royong, independent, bold expression, mutual respect, tolerance, and always consulted. To form the character of a good citizen in order to attain democratic society, education about the values contained within public life is absolutely necessary. The values that exist in society have an important role in shaping the attitude and character of its people.

\section{REFERENCES}

[1] N.R. Yunus, "Aktualisasi Demokrasi Pancasila dalam Kehidupan Berbangsa dan Bernegara," SOSIO DIDAKTIKA: Social Science Education Journal, vol. 2, no. 2, pp. 156-166, 2016.

[2] Y. Latif, Revolusi Pancasila. Jakarta: Mizan, 2015

[3] Yusriando, "Implementasi Mediasi Penal Sebagai Perwujudan NilaiNilai Pancasila Guna Mendukung Supremasi Hukum Dalam Rangka Pembangunan Nasional," Jurnal Pembaruan Hukum, vol. II, no. 1, pp. 23-45, 2015.

[4] Yusdiyanto, "Makna Filosofis Nilai-Nilai Sila Ke-Empat Pancasila Dalam Sistem Demokrasi Di Indonesia," FIAT JUSTISIA, vol. 10, no. 2, pp. 259-272, 2016

[5] I.K. Sudantra, T.I.P. Astiti, and I.G.N.D. Laksana, "Sistem peradilan adat dalam kesatuan-kesatuan masyarakat hukum adat desa pakraman di Bali,” Jurnal Kajian Bali, vol. 7, no. 1, pp. 85-104, 2017.

[6] R. Soepomo, Bab-bab tenang Hukum Adat. Jakarta: Pradnya Paramita, 1987.

[7] T. Pangalila, "Peningkatan Civic Disposition Melalui Pembelajaran Pendidikan Kewarganegaraan (PKn)," Jurnal Pendidikan Kewarganegaraan, vol. 7, no. 1, pp. 91-103, 2017.

[8] U. Winataputra, dkk., Materi dan Pembelajaran PKN SD. Jakarta: Pusat Penerbitan Universitas Terbuka, 2002.

[9] W.G. Suacana, "Budaya Demokrasi dalam Kehidupan Masyarakat Desa di Bali," Jurnal Kajian Bali, vol. 1, no. 1, pp. 88-151, 2011.

[10] I.D.M. Suartha, Hukum dan Sanksi Adat: Persepektif Pembaruan Hukum Pidana. Malang: Setara Press, 2015.

[11] I.G. Sudiarta, "Kemampuan Berbahasa Bali Pada Kalangan Remaja di Desa Pakraman Peraupan Denpasar," Jurnal Penjaminan Mutu, vol. 1, no. 2, pp. 59-70, 2016.

[12] M. Hanafi, "Kedudukan Musyawarah dan Demokrasi di Indonesia," Jurnal Cita Hukum, vol. 1, no. 2, pp. 227-246, 2013 